IJIET, e-ISSN 2548-8430, p-ISSN 2548-8422, Vol. 2, No. 1, January 2018

\title{
IJIET
}

International Journal of Indonesian Education and Teaching http://e-journal.usd.ac.id/index.php/IJIET

Sanata Dharma University, Yogyakarta, Indonesia

\section{PROGRAMMED LEARNING AS SOLUTION FOR SCHOOLS WITH COMBINED CURRICULUM TO WIN ENGLISH ONLINE NATIONAL EXAMINATION}

\author{
Ludwina Lucky Wibakti \\ John Paul School, Indonesia \\ ludwinawibakti@johnpaulschool.sch.id \\ https://doi.org/10.24071/ijiet.v2i1.961 \\ received 12 August 2017; revised 27 November 2017; accepted 19 December \\ 2017
}

\begin{abstract}
Programmed learning which consists of specially designed syllabus and CALL (Computer-Assisted Language Learning) was designed to win English Online National Examination at John Paul's School. It emerged as an answer to the employment of combined curriculum at Satuan Pendidikan Kerjasama School like John Paul's School where Cambridge curriculum is applied to prepare the students to take Cambridge International Examination as added value of the school and national curriculum which is provided at the final grade of each level, grade 9 and grade 12. The application of Online National Examination triggers the empowerment of information technology in formulating, designing, applying, evaluating and improving the Programmed Learning to its effectivity and efficiency. The success of the Programmed Learning application at John Paul's School may inspire other schools with combined curriculum to do similar things.
\end{abstract}

Keywords: CALL (Computer-Assisted Language Learning), combined curriculum, online national examination (UNBK), programmed learning

\section{Introduction}

The education system in Indonesia enables schools to apply curriculum other than the obliged National Curriculum. This privilege is given especially for schools which bear the title of SPK or Satuan Pendidikan Kerjasama. This status enables the respected school to open cooperation with other institutions in other countries. In big cities this is commonly found, not to mention in Jakarta, Bogor, Tangerang and Bekasi where John Paul's School is located.

The consequence of this status is an SPK school may apply more than one curriculum in its teaching and learning process, with international examination on certain stage based on the rules of the international examination the school adopt; Cambridge and Edexcel are what John Paul's School applies, other than theobliged National Curriculum for the students to face National Examination ontheir final stage at grade 6,9 and 12. In this paper, the focus is on grade 9. Intense preparation is not to argue, English is not an exception. 
Therefore grade 7 and 8 are employing Cambridge Curriculum because the students are taking Cambridge Checkpoint Secondary 1 at grade 8 semester 2. Only when the students are sitting at grade 9 that they are fully introduced to National Curriculum in order to prepare them to take National Examination just like other National-based Curriculum Schools. The adjustment is not always easy. The time limitation to master all materials from grade 7 to 9 only in months is another challenge. The National Examination method (with Online / IT-Based) is new. The success of the students in conquering English National Examinationputs the school's reputation at stake.

It is for the purpose of overcoming those four concerns that finally Programmed Learning was designed. The school needs a good system of safely delivering the students to face the adjustment from international materials to national-based materials and finally set them to win National Examination successfully.

\section{Method}

Narrative Inquiry is the research method employed in carrying out the research. The underlying reason is because the data needed are the experience told by the end-user of the Programmed Learning. Narrative inquiry itself, according to Amia Lieblich, Rivka Tuval-Mashiach and Tamar Zilber, refers to any study that uses or analyzes narrative materials. The data can be collected as a story (alife story provided in an interview or a literary work) or in a different manner(field notes of an anthropologist who writes up his or her observations as anarrative or in personal letters). They further specified that their proposed model can be used for the analysis of a wide spectrum of narratives, from literary works to diaries and written autobiographies, conversations, or oral life stories obtained in interviews.

The data were gathered by asking the respondent to write their experiences and impressions as to add some notes after they experienced teaching and learning process using Programmed Learning. Next, analyzing Language Learning History (Oxford,1996:582) of the respondents using Categorical Content-Approach or Content Analysis (Amia Lieblich, Rivka Tuval-Mashiach,Tamar Zilber, 1998) in which categories of the studied topic are defined, and separate utterances of the text are extracted, classified, and gathered into these categories or groups. This approach deals with problem or phenomenon shared by a group of people.

The data needed for this research is whether the employment of Programmed Learning is effective and efficient in order to prepare grade 9 students in facing English Online National Examination to be proven by theachievement in the real English Online National Examination. The respondents were the grade 9 students of John Paul's School batch 2016 - 2017.

A careful data examination was done under the guidance of Categorical Content Perspective or Content Analysis by Amia Lieblich, Rivka TuvalMashiach,Tamar Zilber, 1998 as follows: selection of the subject, define thecontent categories, sorting the material into categories then drawing conclusion from the results. This is further processed by highlighting all related sentences on the verbatim transcriptions, choosing principal sentences to be judged as positive, 
negative or neutral, next is to divide sentences into categories then sum them up as the final research finding.

\section{Findings and Discussion}

Programmed learning itself consists of specially designed syllabus and the application of CALL (Computer-Assisted Language Learning) during English teaching and learning process. Specially designed syllabus needs to 'squeeze' the English national materials from grade $7-9$ and to re-organize its contents to be delivered easily and effectively (not time consuming). In John Paul's School, the re-organization of English National-based Curriculum is done by breaking the materials in 15 Chapters, ranging from the easiest to the more difficult ones. The basis is the content of National Examinations and some references of commonly used books in grade 7,8 and 9. There are two parts in delivering the materials, first is theory of each of 15 Chapters and the second is drills on readings based on each Chapter. The theories provide core information of each chapter is given in 3 meetings ( 6 teaching period / one week) only, very effectively and efficiently delivered.

Technology empowerment in this digital era seems to be a precise tool of formulating CALL program to support the reading drills. It was first designed in the mid of 2013 as a result of discussion with IT division. The need of an effectiveand efficient system in order to keep up with the need of providing enjoyable way of teaching and learning was the primary concern. What are needed is a school integrated IT system which covers the teacher administration stuffs like uploading teaching materials, syllabus, semester and annual plan, scoring and behavior system input, and test administration. Under the heading of Test there are class work, homework and test. These initial facilities are the core of developing the Programmed Learning. Basically all reading materials which consists of 15 Chapters with many Past Papers are uploaded into the system (we call it SISTER - Sistem Administrasi Sekolah). Each Past Paper consists of 50 questions maximum; this is to simplify the scoring system, time allocation per meeting and for the purpose of managing all the questions which are updated each year. Thousands of questions are inside the system, carefully chunked, ready to be downloaded on need basis.

The source of questions is the compilation of all questions appeared in National Examination from the year of 2000 to the latest. This means that the content is always updated each year by uploading the most recent ones. Toprovide interesting materials, they need to be re-typed and re-modeled by modifying the fonts, providing interesting layout by adding pictures and colors also to reduce the students' boredom in finishing the reading drill program so that optimum results are guaranteed.

The Programmed Learning itself has been employed for 4 years, ranging from its original version into the improved ones. A mini research was conducted in order to collect preliminary findings. The following are the categories in which respondents share their experiences. There are benefits (positive) and obstacles (negative) along with it. Let us start with the benefits (positive): 


\section{Effectiveness}

This learning model is proven to be successful in achieving the results we projected. The students' learning trajectory is carefully maintained through the scores saved in the system that any mishaps were to be handled properly. Mostly the students scored higher than the minimum requirement (our school set it for 75); this is a good sign of reaching or even exceeding the target set for national examination later.

\section{Efficiency and Practicality}

Programmed learning is proven to be efficient in terms of time allocation because the students finish the reading drills to master the English National Examination in 4 months. The remaining time is used for material enrichment. The essence is the students have exceeded the benchmark of English National Examination to be supported more by various level of difficulties.

\section{Familiarity with Online Examination Methods}

The application of Online National Examination is new to Junior HighSchool level. Many are afraid of how to do it. Many wonders on what if problem occurs. In short, many are not ready with the new requirement; not only the students, the invigilators, the IT man, the subject teachers and the principal. With the application of CALL, a great deal of anxiety diminish. Better preparation is made concerning the system, the troubleshooting, the methods of carrying out the online examination, the dos and don'ts are well understood. This is because the CALL system is designed as close as possible to the real English Online National Examination. All potential problems are to be eliminated to happen in the real online examination. From the side of the students, they are more than familiar on when and how to start the registration, how to open the questions and to answer them, how to control the number of questions answered and unanswered, how to manage themselves with the time countdown, how to experience reading a long reading passage with only one question at the end then when they click 'Next', other reading passage appears and then only to discover the previous reading passage would be found in other number with different question. This needs good training and good memory in order to locate important information in a what previously was read earlier. How to answer without making notes on the questions and passages. Of course this is different from paper based where they can easily mark the important information on the passage or some parts of the question; where they read one passage with one, two, three, four of five questions following. The CALL program is highly effective in training the students to do these kinds.

\section{Promote Self-Directed Learning and Aptitude}

Programmed learning enables the students to have full control of their reading speed. The CALL program accommodate fast readers to read more passages while the slower readers to have just as they can cope. In short, every student gets his/her portion, just right.

\section{Promote Good Attitude}

When the students are inside the ICT Room, they are busy with their own screen. The reason is clear: time countdown and online system. Different question appear on each screen that cheating is not an option. Everyone follows their own 
pace because they know the amount of Past Paper they have to finish until the end of the CALL Program. They are quiet and focused throughout the English sessions.

\section{Promote Students' Motivation}

The motivation here covers several aspects: first, students have the opportunity of moving to ICT room in which they have different classroom situation. Next, the new learning system excite them a lot, especially when they have full control over their learning process. Thirdly, the pop-up scoring system increase their carefulness before submitting their answer because they know this is a one way ticket, no repetition can be made. Then, they grow their self esteem when they are satisfied with their score; then they start to compare their resultwith other classmates, then a competition spirit grows. Not to mention the enjoyable situation with various layouts, colors and pictures which are absent in paper-based. This reduces boredom and keep the spirit high in finishing reading drills even if the English sessions at the last of the day! The safety and trust abilityof the scoring system, build up the confidence this is worth doing. Lastly, the fact that they speed up much faster than their peers in other school motivate them to gofaster and achieve better; they can be proud of themselves for speeding up faster than they thought. Especially when they come to the end of the CALL Program, the thrill is genuine.

On the other hand, obstacles are present along the way. The following are some which are commonly found:

\section{The quality of internet connection}

The internet connection plays major rule in holding such program because online examination depends on the stability of the internet connection. The school should guarantee that anytime it is needed, it is ready. Otherwise the students will just sit inside the ICT Room, waiting too long to log in, to download the questions, to answer and finally time countdown is not effective anymore. At the end, the students learn very little; the mood is not good; the boredom and dissatisfaction is high.

\section{The quality of school system and facilities}

Other than the internet, the internal school system is the key of the application. In this case the IT man should ensure the system is safe from the possibility of being hacked or being unstable that data are lost or unable to be downloaded. The tools and equipment like personal computer or laptop should meet the required standard that students will not have difficulties in using them. Beware also from the possibility of experiencing blackout during the process.

\section{The quality and availability of IT staff in times of troubles}

Manpower also plays significant role for the success of CALL application. They are expected to have the ability of 'translating' the need of the subject teacher to create a model suitable for the purpose. That is why from the process of formulation of ideas, in the process of designing the program, in the process of application of the program, in the process of evaluation from what happen, the IT man should be able to improve the system; and this will not happen without having knowledgeable IT staff. Digital application is open to unexpected trouble. 
What was working well earlier might be troublesome next. This is when the quality of the IT staff is put at stake. If the school have good manpower to overcome all of these, a good start is well-encouraged.

To sum it all, the respondents are positive toward Programmed Learning and defined it as effective and efficient. However a thorough research is still needed to dig out more facts concerning the application of Programmed Learning.

\section{Conclusions}

The research findings showed that the application of Programmed Learning in English teaching and learning in Grade 9 in winning English National Examination is proven to be highly beneficial. The scores the students gathered during the process of reading drills proven to be indicators of their success in dealing with questions provided in the National Examination. Early precautions are also possible to be done from analyzing the ups and down of the scores stored in the system.

The students are more motivated because the system enables them to proceed or to stop based on their learning aptitude. The layout with colorful pictures and many kinds of fonts are another added value of holding CALL. Another motivation comes from the pop-up scores the students gain after finishinga Past Paper. The competition spirit is there, in order to compete with classmates and other class as a group. There grows the spirit of the group. Classroom situations are mostly advantageous because each focused on their own screen; they are not busy with friends that high focus students are highly accommodated.

When the National Examination day comes, the students are not worried. They know exactly what to do because they have been doing it over and over during the reading drills. The system will not be much different from what they have experienced with our internal CALL system. Reading on screen is easy, the absence of note-taking is not a problem. The students are fully aware of the dos and don'ts of online examination model so that mistakes and troubles are to be avoided. The above brief summary have shown many advantages of a school with combined curriculum in winning English Online National Examination starting from the earliest process toward the final end.

The obstacles are for us to be aware of; dealing with digital world is not that simple and sometimes even unpredictable. Therefore the following are to be prioritized for the smooth application of Programmed Learning, to be precise for holding CALL. The internet connection should be stable to ensure the process of downloading and answering questions, also to keep the time allocation strict. The school should have support system and facilities like the availability of computer laboratory or ICT Room with compatible personal computers or laptops enough for every member of the class. IT man as the operator and supervisor of the whole system should be knowledgeable and ready anytime needed in the process of formulating, designing, applying, evaluating and finally improving the CALL after numerous trials. Without all of the mentioned above, a smooth application will not be possible.

To sum it all after the brief discussions provided earlier, Programmed Learning could be a solution for schools with similar situation to John Paul's 
IJIET Vol. 2, No. 1, January 2018

School - Bekasi. Its application is proven to be highly beneficial over the difficulties present during its application.

\section{References}

Amia, R.T.M. (1998). Narrative research reading, analysis and interpretation. California: Sage Publication.

Berg, G. A. (2003). The knowledge medium: Designing effective computer based learning environment. Hershey: Information Science Publishing.

Creswell, J. W. (2012). Educational research, planning, conducting, and evaluating quantitative and qualitative research. Boston: Pearson Education, Inc.

Douglas, C. A. (2006). Assessing language through computer technology. Cambridge: Cambridge University Press.

Gary B.P.B. (2014). Narrative inquiry in language teaching and learning research. New York: Routledge.

Kim, J.H. (2016). Understanding narrative inquiry. California: Sage Publications, Inc.

Mertova, L.W. (2007). Using narrative inquiry as a research method, an introduction to using critical event narrative analysis in research on learning and teachisng. Oxon: Routledge.

Reinders, M.T. (2010). Task-based language learning and teaching with technology. London: Continuum International Publishing Group.

Rodgers, J. C. (2001). Approaches and Methods in Language Teaching. New York: Cambridge University Press.

Schunk, D. H. (2012). Learning Theories An Educational Perspective . Boston: Pearson Education, Inc.

Stickler, R. H. (2015). Developing Online Language Teaching. Hampshire: Palgrave Macmillan. 